\title{
Estimating Monetary Policy Reaction Functions: Comparison between the European Central Bank and Swedish Central Bank
}

\author{
Benjamin K. Owusu ${ }^{1+}$ \\ ${ }^{1}$ Bielefeld University, Germany
}

\begin{abstract}
This study estimated and compared a forward-looking Taylor-type reaction function between the European Central Bank (ECB) and Swedish Central Bank (Riksbank). First, an estimated baseline model shows that, compared with the ECB, the Riksbank is an aggressor based on its responses to expected inflation and output gap. Second, the estimated baseline model significantly tracks both central banks' actual interest rates, though with certain deficiencies. Furthermore, this study augments the baseline model by exploring additional variables that appropriately describes the ECB and Riksbank's monetary policy. We observed that foreign interest rate, notably the federal funds rate, influence the ECB's monetary policy to a certain degree. Moreover, the ECB's short-term interest rate and real exchange rate impact the Riksbank's monetary policy. Although foreign interest rate explains the ECB and Riksbank's monetary policy, real exchange rate also explains the Riksbank's monetary policy (small open economy) than that of the ECB.
\end{abstract}

Keywords: Monetary policy, Taylor rule, European Central Bank, Riksbank

JEL Classifications: E52, E58

Received 16 February 2020, Revised 9 April 2020, Accepted 27 April 2020

\section{Introduction}

Most literature on monetary policy rules has depicted central bank instruments as an information provider for central banks (Svensson, 2003). Österholm (2005) argued that the quest to gain insights into central banks' behavior over time has prompted researchers to explore and estimate reaction functions for evaluating central banks' action and stance. For example, Taylor (1993) depicted in his seminal paper Federal Reserve Bank's (Fed) short-term interest rate as a linear function of output gap and inflation. Subsequently, the Taylor rule has become popular, of which researchers have developed variant types to explain central banks' behavior ${ }^{1}$. Thus, Beck and Wieland (2008) held that Taylor's (1993) paper on monetary policy rules has altered economic professionals' focus from monetary aggregates to interest rates as a suitable monetary policy instrument. Short-term nominal interest rates have been commonly depicted as a linear function of inflation and output gap. Taylor (1993) conceded that monetary policy 
rules in which monetary authorities raise short-term instruments in response to price level and real income changes above and below targets works significantly. Researchers such as Gerlach and Schnabel (2000), Peersman and Smets (1999), Orphanides (2001), and Rudebusch and Svensson (1998) have demonstrated that simple econometric Taylor-type models provide approximately similar macroeconomic stabilization offered by an optimal rule. These simple rules, which are known to the public, significantly alleviate the uncertainty of monetary policies' future course and prevent macroeconomic instability (Gerlach \& Schnabel, 2000). Walsh (2015) and Ilbas et al. (2012) alluded to this argument and held that such simple rules contribute to monetary policies' robustness despite economic uncertainties.

The European Central Bank (ECB) controlled Europe and the entire euro area's monetary policy since 1999, implying that all countries in the euro area have the same short-term interest rate. The ECB primarily aims at price stability (Belke \& Klose, 2010; Hartmann \& Smets, 2018; Sauer \& Sturm, 2003), which is measured by year-on-year increases in the euro area's Harmonised Index of Consumer Prices (HICP) (Gerlach \& Schnabel, 2000). Various central banks, such as the Bank of Sweden, the Bank of Canada, the Bank of New Zealand, and the Bank of England, have adopted inflation targeting as part of their objective (Drakos and Kouretas, 2015). Inflation targeting implies increasing nominal interest rates that significantly affect real interest rates when the expected inflation level exceeds its long run rate (Clarida et al., 1998). The Swedish Central Bank (Riksbank) aims to limit consumer price index to $2 \%$ with a tolerance interval of plus and minus one percentage point (McCallum, 1996). This objective may be viewed as extreme inflation targeting. Inflation targeting implies the central bank's significant emphasis on the inflation objective in its decision-making at the expense of other monetary policy goals to conduct its monetary policy (Friedman, 2004). Giovazzi and Mishkin (2006) analyzed a case that sets price stability justification and a nominal anchor as significant objectives of central banks' monetary policy. They proposed three main arguments: inflation is costly; monetary policy cannot raise output and employment levels in the long run; and time-inconsistency problems exist. Therefore, price stability is expected as one of the core objectives of most central banks.

According to Ullrich (2003), most existing literature on monetary policy reaction functions focus on one central bank only and disregarded foreign interest rate decisions, particularly from large economies. This topic could be insufficient for monetary policy as foreign interest rates in an open economy influence monetary policy (Österholm, 2005). Clarida et al. (1998), Belke and Klose (2010), Hayo and Hoffman (2006), Österholm (2005), and Ullrich (2003) have performed comparisons between central banks' reaction functions. However, their comparisons

1) Numerous seminal papers have estimated variant Taylor-type reaction function, including but not limited to Clarida et al (1998), Galimberti and Moura (2013), Gerlach and Schnabel (2000), Sauer and Sturm (2003), Ullrich (2003), and Woodford (2001). 
focus mainly between the ECB and the Fed and between independent central banks before the ECB era.

This paper mainly aims to compare the monetary policy reaction functions of two independent central banks. We will examine one central bank in a monetary union and then compare it with another central bank outside a monetary union. Since the ECB and Riksbank adjust their short-term interest rates in response to macroeconomic environmental changes, empirically investigating the factors that drive their interest rate decisions will be feasible. The ECB is selected for this study because it conducts monetary policies in the euro area. In addition, Sweden remains a key member country of the European Union (EU) but has an independent central bank and conducts its monetary policy. Furthermore, Sweden has quality data to represent a non-monetary union central bank as basis of this study. The study will answer the following questions. Can the Taylor-type reaction function describe the ECB and Riksbank's behavior? Do the Riksbank and ECB's monetary policy reaction functions differ significantly? Do the Riksbank and ECB target variable stability other than inflation and output gap? Do interdependencies exist between the ECB and Riksbank? Finally, do external monetary policies influence the $\mathrm{ECB}$ and Riksbank?

This study will adopt and modify the Taylor-type reaction function for each central bank based on available macroeconomic conditions and findings from literature. Following Clarida et al. (1998), this present study will estimate a forward-looking reaction function using the generalized method of moment (GMM) estimation technique for the ECB and Riksbank to address the above research questions. GMM estimators are more efficient than common methods of moments, such as OLS and two-stage least squares, regardless of the presence of heteroscedasticity and serial autocorrelation problems (Wooldridge, 2001). The sample data consist of monthly time series data from 2003:1 to 2018:12 for the euro area and Sweden. To explore the two central banks' interdependence, the ECB's decision variable must be incorporated into the Riksbank's reaction function to test its significance. This paper contributes to the literature as follows. First, it contributes to the existing literature on monetary policy rules. Second, the study provides monetary policy recommendations for policymakers in small open economies, particularly where exogenous influences from large economies, such as the EU, are experienced.

The rest of the paper is structured as follows. Section 2 discusses monetary policy rules and the proposed reaction function. Section 3 presents the econometric estimation of study results and related discussions. Lastly, Section 4 summarizes the results and conclusion of the study.

\section{Monetary Policy Rules and the Reaction Function}

This section sets the foundation of discussions on monetary policy rules. We begin by 
examining optimal policies versus simple policy instrument rules, and then targeting monetary policy regimes shall be discussed. The subsection below introduces the proposed monetary policy reaction function and its related discussions.

\section{A. Instrument rules versus optimal policy}

The peak of inflation recorded around 1980 has led researchers and monetary policy practitioners to explore principles that help predict expectations and stabilize inflation (Berg et al., 2004). Most researchers have adopted two main approaches to specifying monetary policy functions in new Keynesian macroeconomics, namely, optimal policy and simple instrument rules (Ibas et al, 2012).

An optimal policy specifies a central bank's objective function after which policy instruments are derived optimally (Walsh, 2017). This approach aims to minimize a central bank's loss function given certain available information. Hence, central banks are considered to have optimal behavior because they take policy decisions based on an objective function (usually a loss function) and restrictions imposed by an economic structure. Woodford (2003) provided a comprehensive connection between an approximation of a representative agent's utility and a quadratic loss function developed by earlier researchers. Woodford's (2003) model showed that a standard function that can be used to represent a central bank's quadratic loss function can be approximated by the following:

$$
\sum_{i=0}^{\infty} \beta^{i} V_{t+i} \approx E t \sum_{i=0}^{\infty} \beta^{i}\left[\pi_{t+i}^{2}+\lambda\left(y_{t+i}-y^{*}\right)^{2}\right]+\varphi
$$

Where $y_{t}$ is the output gap, $\pi_{t}$ is the inflation, $V_{t}$ is the representative agent's utility, $\lambda$ measures the trade-off between inflation volatility and real economic activity, and $\varphi$ represents other variables that are independent of a monetary policy. The above equation represents the monetary authority's objective (Walsh, 2017). Solving for inflation and output gap terms involves expanding the above equation and a first- and second-order linear approximation to obtain a good degree of accuracy. Moreover, Aoki's (2001) optimal policy model utilized a second-order Taylor series approximation of a central bank's loss function around a steady state in a sticky price model to identify macroeconomic variables required for equilibrium stabilization. Galí and Monacelli (2005) derived an optimal monetary policy for a small open economy. Here, they employed a second-order welfare approximation of a representative consumer in a Calvo sticky price model. Other optimal monetary policy models have been explored and used in literature by researchers such as McCallum and Nelson (1999), Svensson and Woodford (2003), Rotemberg and Woodford (1997), Walsh (2017), and Fuhrer (1997). Such models require 
high-level mathematical rigor and micro-foundations and rely on stringent state of the economy assumptions. Moreover, such optimal policy rules are inefficient in various models due to their complexity and stringent assumptions in their formulation (Taylor, 1999).

On the contrary, simple instrument rules stipulate how a monetary policy instrument should be made to react to other macroeconomic variable changes, particularly inflation, and output gap. Such instrument rules depict the instruments as a function of a backward- (predetermined) or forward-looking variables (Svensson, 1999). Orphanides (2007) opined that simple policy rules that are understood by the public promote accountability and central banks' credibility with regard to future policy actions. This condition is advantageous for economic agents, such as businesses, households, and financial markets, who need simple policy decisions for forecasting and forming expectations. Moreover, when policymakers commit to simple rules, such as the Taylor rule, they avoid time-inconsistency problems that occur due to discretionary policies (Walsh, 2015). Therefore, the Taylor rule remains the best known instrument rule (Walsh, 2017). Simple rules, such as the Taylor rule, have defined central bank policies and are comparably more robust to model uncertainty compared with optimal policy (Ibas et al., 2012; Levin \& Williams, 2003; Taylor, 1999). Therefore, researchers have used variant types of the Taylor rule model in empirical macroeconomic research to estimate monetary policy reaction functions.

Taylor (1993) remarkably contributed to monetary policy when he depicted the Fed funds rate as a function of inflation and output gap. The rule describes how the Fed sets its policy instruments in response to macroeconomic variables. Taylor's original reaction function is as follows:

$$
r=p+0.5 y+0.5(p-2)+2
$$

Where $r$ represents the short-term interest rate, $p$ represents the inflation rate over a four-quarter period, and $y$ represents the output gap, which is the percentage deviation of real GDP from the target.

Based on Equation (1) Fed's target inflation rate is assumed at $2 \%$. The equilibrium real interest rate for the US economy was assumed at $2.2 \%$. The above policy rule significantly corresponds to the Fed's policy performance and depicts the direction for the Fed funds rate between 1987 and 1992 (Taylor, 1993). Based on Equation (1), interest rate is expected to respond to inflation and output gap changes. Thus, Taylor (1993) conceded that following a central bank's policy rule, such as Equation (1), may not be practical but only serve as a guide for policymakers. Similarly, Svensson (2003) argued that central banks are assumed to be forward-looking and optimizing. Hence, a simple mechanical instrument rule is unlikely to depict its optimization solution. Nevertheless, simple rules, such as the Taylor rule, have 
been accepted not only as an appropriate guide to actual policy but also as more robust approach to model uncertainty than optimal rules (Ilbas et al., 2012; Taylor, 1999). Thus, Equation (1) can be simplified as follows:

$$
r=1+0.5 y+1.5 p
$$

Equation (2) shows that the estimate for inflation is 1.5 , whereas that of the output gap is 0.5. Taylor (1993) found that these values correspond to the US Fed funds rate behavior during the Greenspan period. Ilbas et al. (2012) argued that although simple rules, such as the classical Taylor rule, are not an optimized model, they have reasonable parameter values. The Taylor principle was developed from the Taylor rule and stresses that nominal interest rate must be raised by more than 1 percentage point (pp.) in response to a $1 \mathrm{pp}$. increase in inflation. This principle implies that when inflation rises above target levels by $1 \mathrm{pp}$. (due to a macroeconomic shock), then the nominal interest rate must be increased by more than $1 \mathrm{pp}$. to increase the real interest rate, thereby dampening the effect of macroeconomic shock. Walsh (2017) revealed that a policy that fails to react by increasing the nominal interest rate sufficiently when inflation rises would increase the aggregate demand and output. Therefore, this principle constitutes an important policy tool in the context of the new Keynesian economics. For instance, Lubik and Schorfheide (2007) held that the Fed's inability to respond sufficiently to inflation in the 1970s explains the rise in inflation during that period. Hence, central banks must intervene by adjusting interest rates in response to inflationary pressures, particularly if they aim to control inflation.

\section{B. Targeting regimes}

Researchers such as Svenson (2001) and Söderström (2008) have argued that a targeting regime characterizes the Riksbank's monetary policy. Hence, this subsection sheds light on a targeting regime's characteristics.

A monetary policy regime where central banks are given a specific objective and face certain constraints is referred to as a targeting regime (Berg et al., 2004; Walsh, 2017). A targeting regime can also be viewed as a situation where central banks adopt a rule for adjusting their instrument in the presence of deviations between the current value of the targeted variable and its target level (McCallum, 1996). Targeting regime assumes that central banks have rational decision-making and an objective function with constraints imposed by economic structures.

The most commonly discussed targeting regime is inflation targeting (Walsh, 2017), which involves stabilizing inflation around a target level. Here, central banks are tasked to communicate formally an inflation target and forecast. Svensson (2001) advocated a targeting 
regime, where he argued that it empirically captures a monetary policy decision in inflation targeting countries, such as New Zealand, the UK, and Sweden. Following Walsh (2017), a targeting regime assumes that central banks face the following objective function:

$$
L_{t}=0.5 E_{t} \sum_{i=0}^{\infty} \beta^{i}\left[\left(\pi_{t+i}-\pi^{*}\right)+\varphi x_{t+i}^{2}\right]
$$

Where $\pi^{*}$ denotes the inflation target rate and $\varphi$ denotes the weight that the central bank attaches to the output gap relative to inflation fluctuations. $\pi$ represents inflation, whereas $x$ denotes the output gap. Central banks seek to solve the minimization problem in Equation (3) under a targeting regime and formulate a discretionary policy2). Strict inflation targeting refers to $\varphi=0$ because only inflation is the target variable, whereas $\varphi>0$ connotes flexible inflation targeting regime because inflation and output gap are target variables (Svensson, 2001).

Berg et al. (2004) argued that central banks practicing explicit inflation targeting concede that their policies are based on forecasts and belong to the flexible inflation targeting category, not the strict targeting category. However, contrary to the flexible targeting claims, Faust and Henderson (2004) observed that central banks practicing inflation targeting tend to emphasize their specific target horizon more than the intertemporal optimization implied in Equation (3). In addition to inflation targeting, other targeting regimes include price level, nominal income growth, and average inflation targeting (Walsh, 2017).

\section{Monetary policy reaction function}

This subsection will provide the foundation of the monetary policy reaction function used in this paper. We discuss the baseline model and then derive a forward-looking reaction function with interest rate smoothing based on central banks' imposed assumptions. The subsection ends with discussions on an augmented monetary policy reaction function.

\section{Forward-looking monetary policy reaction function: baseline case}

The original Taylor rule is considered to be backward-looking, that is, central banks consider only inflation and output gap's lagged values when setting interest rates. For instance, in period $t$, the central bank sets the interest rate based on inflation and output gap in period $t-1$ until $t$ given a one period horizon. Ball (1999) and Svensson (1997) also developed a backward-looking interest rate model synonymous to the Taylor rule. Ball (1999) conceded that an ideal model has micro-foundations of a forward-looking structure that captures inertia. The original Taylor

2) Conducting a discretionary monetary policy implies that central banks can change their instruments at any time, unlike a credible rule-based monetary policy regime. Under rule-based regime, central banks commit to adopt a policy rule to gain credibility advantages associated with the rule (see Walsh, 2015; Taylor, 1993). 
rule has no provisions for expected inflation and monetary policy inertia. The assumption that policymakers are forward-looking and respond to expected future inflation as opposed to previous or lagged inflation implies that a forward-looking model is more realistic compared with backward-looking models.

Following Clarida et al. (1998), we set a target rate that is dependent on forecast inflation and output gap. Hayo and Hoffman (2006) referred to this approach as the industry standard specification that has widely been used in most research on Taylor rules. Therefore, our motivation is expected to stem from this approach. Hence, we denote the following:

$$
r_{t}^{*}=\bar{r}+\beta\left(E\left[\pi_{t+n} \mid \Omega_{t}\right]-\pi^{*}\right)+\gamma\left(E\left[y_{t} \mid \Omega_{t}\right]-y_{t}^{*}\right)
$$

Where $r_{t}^{*}, \bar{r}$, and $\pi_{t+n}$ denote the target short-term nominal interest rate, long-term equilibrium nominal interest rate, and inflation between period $t$ and period $t+n$, respectively. $\pi^{*}$ and $y_{t}{ }^{*}$ represent the target inflation and output target, respectively, whereas $y_{t}$ represents real output. $\beta$ and $\gamma$ are coefficients representing inflation gap and output gap, respectively, whereas $\Omega_{t}$ denotes the set of information available to central banks at the time of setting interest rates. Central banks are likely to have incomplete explicit information about inflation and output gap. They use all information available to form inflation and output gap concepts. Hence, the expected inflation and output gap values depend on information available to central banks.

Denoting $\alpha=\bar{r}-\beta \pi^{*}$ and $x_{t}=y_{t}-y_{t}{ }^{*}$ and simplifying Equation (4), we obtain the following:

$$
\left.r_{t}^{*}=\alpha+\left[\pi_{t+n} \mid \Omega_{t}\right]+\gamma E\left[x_{t} \mid \Omega_{t}\right]\right]
$$

Equation (5) depicts a forward-looking Taylor reaction function when central banks are assumed to be forward-looking. Thus, they respond to expected inflation and output gap, showing realistic policy-making. Central banks alter nominal interest rates in response to expected inflation that affects the real interest and hence the economy. Therefore, we generate Equation (6) below for real interest rate in the ex-ante sense using the expression $\overline{r r}=r_{t}$ $\mathrm{E}\left[\pi_{t+n} \mid \Omega_{t}\right]$. Incorporating this expression into Equation (4) and rearranging the terms, we obtain the following:

$$
\left.r r_{t}^{*}=\overline{r r}+(\beta-1)\left(E\left[\pi_{t+n} \mid \Omega_{t}\right]-\pi^{*}\right)+\gamma E\left[x_{t} \mid \Omega_{t}\right]\right]
$$

Where $r r_{t}{ }^{*}$ is the ex-ante real interest rate and $\overline{r r}$ is the long-term equilibrium real interest rate. Equation (6) intuitively shows how real interest rate adjusts relative to the equilibrium real interest rate when inflation or output gap deviates from their target levels. Key to this 
equation is the size of parameters $\beta$ and $\gamma$, which represent the weighted deviation of expected inflation from its target level and output gap, respectively. Whether real interest rate is positive or negative depends on whether $\beta$ is more than 1 and the sign of $\gamma \cdot \beta>1$ is considered stabilizing because the target real interest rate adjusts to stabilize inflation, provided $\gamma$ is positive (Clarida et al., 1998). Conversely, $\beta<1$ implies that the target real interest rate moves to accommodate inflation. The same argument also applies to $\gamma$. Thus, that if $\gamma>0$, then the situation is stabilizing, whereas $\gamma<0$ implies a destabilizing regime in the new Keynesian macroeconomic context. Therefore, the magnitude of $\beta$ and $\gamma$ is a significant standard for evaluating central banks' policy rules.

\section{Forward-looking monetary policy reaction function with interest rate smoothing}

Most economists agreed that monetary policy effects are usually achieved with lags of more than 1 year (Berge \& Grottheim, 1997; Sauer \& Sturm, 2003). Hence, the simple Taylor rule requires augmentation to capture policy inertia. A notion states that central banks prefer smoothing interest rate changes. Goodfriend (1991) justified central banks' interest rate smoothing preference by asserting that it eliminates the tendency of rates' temporary surprise movements. Furthermore, central banks' preference to moving policy interest rates over sharp reversal policy rates has been observed since the 1990s (Rudebusch, 2002). Interest rate smoothing significantly alleviates the fear of disrupting capital markets and credibility loss from large policy fluctuations (Clarida et al., 1998). Therefore, central banks tend aversely respond to large interest rate fluctuations (Ullrich, 2003).

Authors such as Rudebusch (2002) have contested the general notion of central banks' deliberate interest rate smoothing. He opined that the presence of a lagged interest rate does not imply central banks' preference to gradual interest rate smoothing. He argued that this preference could be due to imperfect information about the degree of economic disturbance persistence that may cause central banks, such as the Fed, to gradually adjust interest rates. The argument of whether central banks deliberately smooth interest rates versus argument imperfect information about economic disturbance persistence is outside the scope of this paper. However, this study will introduce a lagged interest rate term that allows the actual rate to partially adjust to the target rate and thus capture interest rates' short -term dynamics. In addition, introducing the lag term of the interest rate at the right-hand side of the reaction function equation eliminates the error term's possible serial correlation (Clarida et al., 2000). Hence, we denote the following:

$$
r_{t}=(1-\rho) r_{t}^{*}+r_{t-1}^{*}+v_{t}
$$

Where $\rho \in[0,1]$ represents the degree of interest rate smoothing (or degree of inertia), as 
this determines the speed of the smoothing process, whereas $v_{t}$ is an exogenous interest rate shock term ${ }^{3}$.

Combining Equations (5) and (6) provides the following rule for nominal interest rate:

$$
\left.r_{t}=\rho r_{t-1}+(1-\rho) \alpha+\beta E\left[\pi_{t+n} \mid \Omega_{t}\right]+\gamma E\left[x_{t} \mid \Omega_{t}\right]\right]+v_{t}
$$

Next, unobserved forecast variables are eliminated by re-writing Equation (8) in terms of realized variables. Thus, we obtain the following:

$$
r_{t}=\rho r_{t-1}+(1-\rho) \alpha+(1-\rho) \beta \pi_{t+n}+(1-\rho) \gamma x_{t}+\varepsilon_{t}
$$

Where $\varepsilon_{t}=-(1-\rho)\left(\beta \pi_{t+n}-E\left[\pi_{t+n} \mid \Omega_{t}\right]+\gamma\left(x-\mathrm{E}\left[x_{t} \mid \Omega_{t}\right]\right)+v_{t}\right.$ constitutes the error term and is a linear combination of the forecast error of inflation, output, and exogenous shock term $v_{t}$. Equation (9) constitutes our baseline model and is considered a forward-looking reaction function, where explanatory variables comprise future and contemporaneous variables. Equation (9) reduces to a backward-looking reaction function when explanatory variables are lagged terms.

It is noteworthy that our empirical model does not identify explicitly $\pi^{*}$ and $\bar{r}$, which are the inflation target and long-term equilibrium nominal interest rate, respectively. However, we can use the relationship $\alpha=\bar{r}-\beta \pi^{*}$ to solve for $\bar{r}$. Inflation target is already known for central banks practicing inflation targeting. Alternatively, if the sample data are large, then the average of the nominal interest rate can be used to compute $\bar{r}$ after which $\pi^{*}$ can be obtained.

\section{Application of GMM to the taylor rule}

GMM application to the Taylor rule implies that we select an instrument set, such as $w_{t}$, which is within the information set of central bank $\Omega_{t}^{4}$ ). Vector $w_{t}$ is chosen such that it is orthogonal to the error term $\varepsilon_{t}$. Likely candidates of $w_{t}$ include lagged terms of explanatory variables or other current variables that are uncorrelated with $\varepsilon_{t}$. Using GMM implies that information about error term distribution is not required. However, the orthogonality condition is sufficient (Gerdesmeier \& Roffia, 2003). Next, we set the condition $\mathrm{E}\left[\mathcal{E}_{t} \mid w_{t}\right]=0$ and apply the orthogonality condition for Equation (9) to obtain the following:

$$
E\left[r_{t}-\rho r_{t-1}-(1-\rho)\left[\alpha+\beta \pi_{t+n}+\gamma x_{t}\right] \mid w_{t}\right]=0
$$

3) We assume $v_{t}$ is i.i.d, which could be a pure random aspect of policy or could also emanate from the imperfect forecast of idiosyncratic reserve demand by the central bank. This could possibly be due to delay by the central bank to supply reserves to dampen or counteract the shocks (see Clarida et al., 1998).

4) We assume that the instrument $w_{t}$ constitutes the information available at the disposal of the central bank at the period it chooses its interest rate. 
The parameter vector of interest here is $[\alpha, \beta, \gamma, \rho]$, which will be estimated using the GMM model. Remarkably, the number of potential instruments in our model is likely to be more than the parameters. This condition implies that the number of orthogonality conditions exceeds our parameter vector. Hence, the model is over-identified, leading to misspecification issues, and further inconsistent estimations. Therefore, over-identifying restrictions need to be tested to ascertain the model's validity.

\section{Estimation, Results, and Discussions}

Subsection III(A) begins with the discussions of estimation results emanating of the baseline Taylor rule model. These results will be compared with the actual interest rate to ascertain they are similar with the actual interest rates set by the two central banks. Subsection III(B) presents the results after varying the two central banks' inflation horizons to determine which horizon presents central banks' reasonable behavior. Subsection III(C) augments the baseline model by allowing certain selected variables to enter the baseline model to arrive at a good description of the two central banks' monetary policy.

\section{A. Baseline model estimation}

In this subsection, we would estimate our baseline model based on Clarida et al. (1998). Sample data for the euro area and Sweden are based on monthly data from 2003:1 to 2018:12. The ECB started conducting monetary policy in 1999. Hence, estimating its policy function after this date is feasible. Furthermore, the ECB's monetary policy changes of individual EMU countries could result in a monetary policy shock or instability, especially at the initial operating years of the ECB. The author believes estimating the ECB function from 1999 would expose the model to changeover shocks, which is beyond the scope of this study. Hence, selecting 2003 allows stability in the ECB's monetary policy process. The paper adopted the same sample period for the Riksbank and compares the two central banks.

Our specification in Equation (8) is forward-looking in nature with interest rate smoothing. The short-term interest rate responds to a future inflation forecast 5 ), output gap, and one-month lagged interest rate. The instruments for the euro area are as follows: 8 lags each of the interest rates (EONIA), inflation (HICP), output gap, world oil prices, and world commodity prices and a constant. For Sweden, we use 8 lags of repo rates, 8 lags of output gap, 12 lags of inflation, 8 lags of world oil prices, and a constant. As estimation technique used is GMM through Eviews with Newey and West (1987) estimation weighting matrix for computing

5) For the ECB and Riksbank, we assume a 1-year inflation forecast horizon. Hence, in Equation (8), we set $n=12$. 
heteroscedasticity and autocorrelation consistent (HAC) standard errors. Table 1 shows the estimation results of the baseline model for the euro area and Sweden.

Evidence from past empirical papers on Taylor reaction functions shows positive estimates for inflation, output gap, and lagged endogenous variable. From Table 1, we can observe higher inflation estimate for the Riksbank $(\beta=1.92)$ compared with the $\operatorname{ECB}(\beta=1.154)$. This result could suggest that the Riksbank reacts aggressively to inflation compared with the ECB. Inflation estimates for the ECB and Riksbank are above 1, suggesting the inflation-stabilizing motive of both regimes because $\gamma$ is positive. Clarida et al. (2000) stipulated that interest rate rules characterized by $\beta>1$ are stabilizing, provided that $\gamma>0$, whereas rules with $\beta \leq 1$ are either destabilizing or accommodating of shocks in the context of new Keynesian macroeconomics. Hence, the sign of $\beta$ and $\gamma$ have policy implications. We have noticed that the baseline model characterizes a stabilizing regime. Then, inflation estimates meet the Taylor principle, which indicates that an increase in inflation by $1 \%$ should be accompanied by more than $1 \%$ corresponding increase in the nominal interest rate to impact the real interest rate and stabilize the rise in inflation.

Table 1. Estimation Results for the Baseline Model

\begin{tabular}{|c|c|c|c|}
\hline Variables & $\mathrm{ECB}$ & \multicolumn{2}{|c|}{ Riksbank } \\
\hline Inflation $_{t+n}(\beta)$ & $1.154^{* * *}(0.008)$ & $1.92^{* * *}$ & $(0.008)$ \\
\hline Output $\operatorname{gap}_{t}(\gamma)$ & $0.57^{* * *}(0.001)$ & $0.98^{* *}$ & $(0.002)$ \\
\hline Interest $\operatorname{rate}_{t-1}(\rho)$ & $0.97^{* * *}(0.004)$ & $0.98^{* * *}$ & $(0.006)$ \\
\hline Constant $(a)$ & $-1.37^{* * *}(0.014)$ & $-2.28^{* * *}$ & $(0.016)$ \\
\hline Number of observations & 192 & 192 & \\
\hline$R^{2}$ & 0.992 & 0.990 & \\
\hline S.E of regression & 0.11 & 0.13 & \\
\hline J-statistics (J-Prob) & 21.50 & 26.27 & $(0.79)$ \\
\hline
\end{tabular}

(Notes) (i) Estimation of the equation $\left.r_{t}=(1-\rho) \alpha+\rho r_{t-1}+(1-\rho) \beta\left[\pi_{t+n} \mid \Omega_{t}\right]+(1-\rho) \gamma\left[x_{t} \mid \Omega_{t}\right]\right]+\varepsilon_{t}$ using GMM, where $\mathrm{n}=12$ for the ECB and Riksbank. Standard errors of coefficients are depicted in parenthesis. Estimated weighting matrix based on Newey and West (1987) for computing HAC standard errors in EViews.

(ii) Significance at $10 \%, 5 \%$, and $1 \%$ are denoted by $* * *$, and $* * *$, respectively. Durbin Watson statistics for Sweden and the euro area are 1.11 and 0.90 , respectively.

(iii) For the euro area, we use 8 lags each of interest rates (EONIA), inflation (HICP), output gap, world oil prices, and world commodity prices and a constant. For Swedish data, we use 8 lags of repo rates, 12 lags of inflation, 8 lags of output gap, 8 lags of the world oil prices, and a constant

Inflation estimate for the ECB and Riksbank are highly significant at $1 \%$ level with standard errors of 0.008 each. However, output gap estimate, which is the coefficient that measures the sensitivity of the cyclical variable, is lower compared with inflation. We observe that the output gap estimate of the $\operatorname{ECB}(\gamma=0.57)$ is relatively lower than that of the Riksbank $(\gamma=0.98)$. This finding could suggest that the Riksbank reacts more aggressively to business cycles compared with the ECB. Both estimates are statistically significant at $1 \%$ level. 
The smoothing parameter for both regimes is significantly high $(\rho=0.97$ for ECB and $\rho=0.98$ for Sweden), which indicates a high degree of inertia in monetary policy by both regimes. This finding implies that both central banks tend to smooth adjustments considerably in the interest rate. The coefficients on the constant terms are negative for the ECB $(\alpha=-1.37)$ and Riksbank $(\alpha=-2.28)$. The baseline model recorded high $R^{2}$ for both regimes $(99.2 \%$ for the euro area and $99.0 \%$ for Sweden).

To test the robustness of our model, we compute both regimes' inflation target and compare them with both banks' actual target to ascertain if they are approximately the same. Thus, we assume that the observed sample average of interest rate represents the equilibrium nominal interest rate (similar to the Clarida et al.'s [1998] framework). To obtain the estimate for inflation targets $\pi^{*}$, we recall the following relationship:

$$
\alpha=\bar{r}-\beta \pi
$$

Inserting the constant term, estimates for equilibrium nominal interest rate6) and inflation target into Equation (11), we obtain the following:

$$
-1.37=1.15-\left(1.154 \pi^{*}\right)
$$

Simplifying, we obtain $\pi_{E C B}^{*}=2.18$.

A comparison between our baseline model's the inflation target $(2.18 \%)$ and the ECB's actual inflation target (approximately $2 \%$ ) shows that that the values are nearly equal, though the baseline model predicted a slightly higher inflation target. Hence, our baseline model effectively predicts the ECB's inflation target.

Similarly, we calculate Sweden's inflation target through our model using Equation (11) and inserting the figures into Sweden. Then, we obtain the following:

$$
-2.28=1.31-\left(1.92 \pi^{*}\right)
$$

\section{Simplifying we obtain $\pi_{\text {Riksbank }}^{*}=1.86$.}

Hence, Sweden's inflation target based on our model $(1.86 \%)$ is lower than the actual target but close to the Riksbank's actual inflation target (2\%).

Next, we check for the validity of our instruments. Thus far, we have argued that our instruments correlate with the regressors, not the error term. Correlation in instruments with

6) The equilibrium nominal interest rate for the euro area and Sweden was calculated using the mean of the nominal interest rate of the sample data. The equilibrium nominal interest rate for the euro area is 1.15 , whereas that of Sweden is 1.31 . 
the error term violates the orthogonality condition discussed in Subsection II(D).

We have argued that the central bank has instrumental variable information and uses them when conducting monetary policy. Hence, we include the lagged values of repo rates, inflation, output gap, effective real exchange rate, world oil prices, and world commodity prices, with the assumption that they do not correlate with the error term. Any variable that impacts interest rate but not included as a regressor is considered an error term. If lagged values of such variables are added to the instruments, then the lagged values and error term may potentially correlate, hence violating the orthogonality condition.

Considering that the number of instruments is more than that of the regressors, we conducted the test of over-identifying restrictions discussed in Subsection II(D) to ascertain if the orthogonality condition is violated. When conducting the J-Test, we test the null hypothesis that the central banks adjust nominal interest rates based on Equation (8) such that the residual $\left(\varepsilon_{t}\right)$ is orthogonal to variables in the information set $\left(\Omega_{t}\right)$. On the contrary, the alternative hypothesis implies that the central bank sets its nominal interest rate in contrast with Equation (8). However, the nominal interest rate is set in response to variations of other current or lagged variables, which are not included in the information set. Table 1 shows that the probability of the J-statistics (ECB: 0.98; Riksbank: 0.79) implies that we cannot reject the null hypothesis at $1 \%, 5 \%$, and $10 \%$ for the ECB and Swedish data. Therefore, we can infer that the instruments correlate with the regressors but not with the error term, hence satisfying the over-identifying restriction condition. Therefore, the instruments used are valid.

Figures 1 and 2 show the path of our baseline Taylor interest rate model compared with the actual interest rate for the euro area and Sweden, respectively. In the case of the ECB, although the baseline Taylor interest rate tracks the ECB's actual interest rate, the two interest rates deviate, and a confidence band is wide. In certain cases, the actual interest rates go out of the confidence bands as shown in Figure 1. This finding implies that our baseline model has less prediction accuracy. Therefore, our baseline model cannot sufficiently describe the ECB's monetary policy. Our model needs to be augmented with other variables to resemble both central banks' actual monetary policy. In the case of the Riksbank, we observe that the baseline Taylor interest rate significantly tracks the actual interest rate but with few deviations and wider confidence band. 
Figure 1. Baseline taylor interest rate versus the euro area's actual interest rate

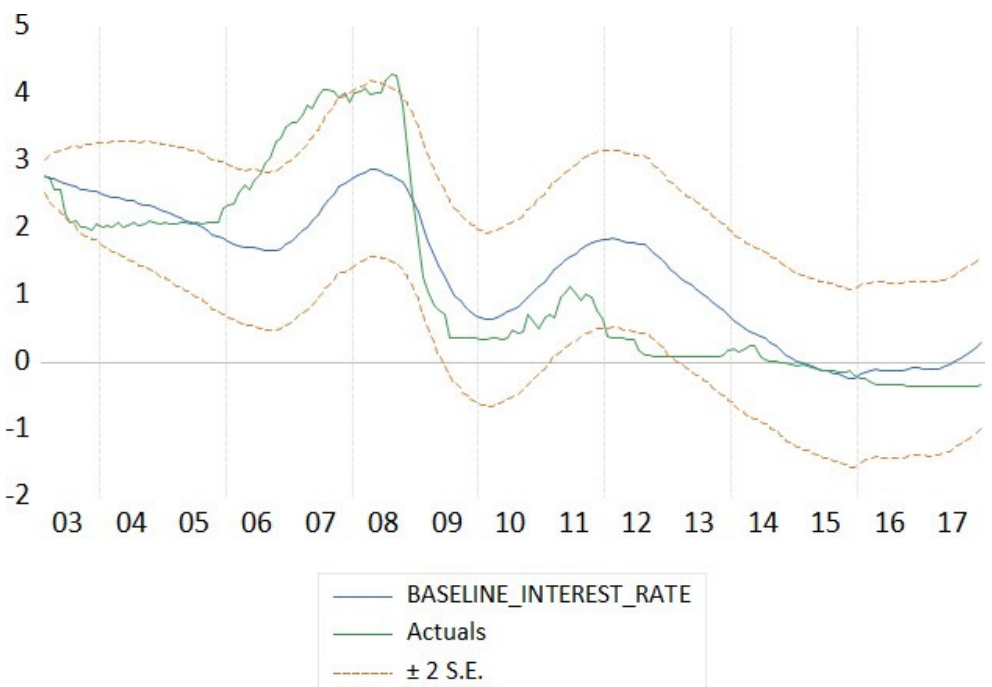

Figure 2. Baseline taylor interest rate versus sweden's actual interest rate

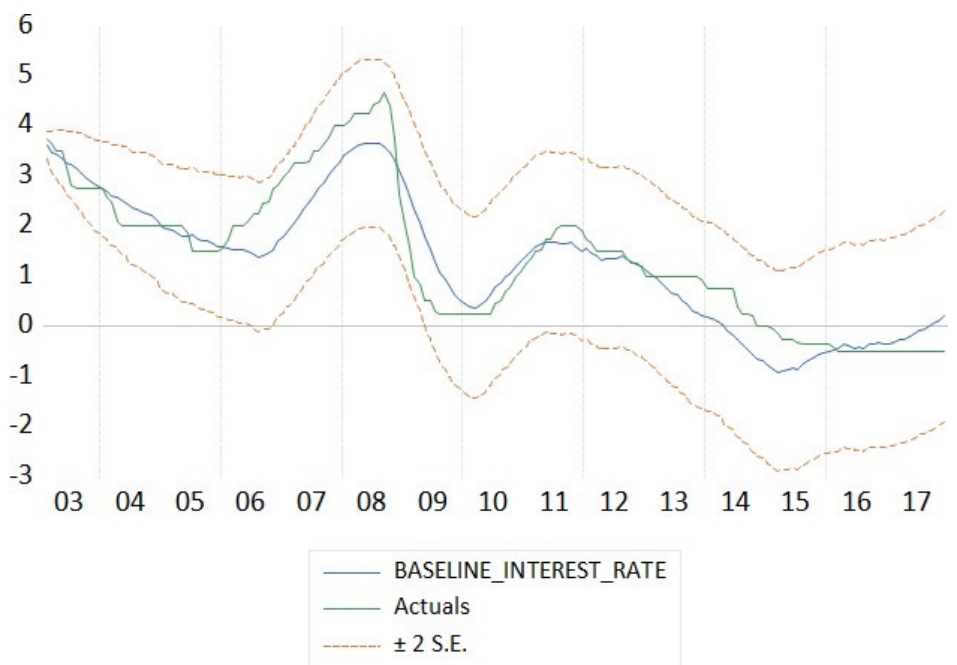

\section{B. Changing the inflation forecast horizons}

Thus far, we have assumed that the two central banks' inflation forecast horizon is 12 months. We explore alternative inflation horizons to test the robustness of our baseline model. This test will determine whether the coefficients on our variables will change and find out which horizon best describes the two central banks' monetary policy. Following Hayo and Hoffman (2006), we test the reaction function with 12, 9, 6, and 3 months. Table 2 below depicts the baseline model under different time horizons. 
Table 2. Changing the Inflation Forecast Horizons for the ECB ( $\beta=$ Inflation Estimate; $\gamma=$ Output Gap Estimate; $\alpha=$ Constant; and $\rho=$ Estimate for Smoothing Parameter)

\begin{tabular}{|c|c|c|c|c|c|c|c|c|}
\hline & \multicolumn{2}{|c|}{$\beta$} & \multicolumn{2}{|c|}{$\gamma$} & \multicolumn{2}{|c|}{$a$} & \multicolumn{2}{|c|}{$\rho$} \\
\hline 12 months ahead & $1.15^{* * *}$ & $(0.008)$ & $0.57^{* * *}$ & $(0.001)$ & $-1.37^{* * *}$ & $(0.014)$ & $0.97^{* * *}$ & $(0.004)$ \\
\hline 9 months & $1.38^{* * *}$ & $(0.01)$ & $0.45^{* * *}$ & $(0.001)$ & $-1.73^{* * *}$ & $(0.018)$ & $0.97^{* * *}$ & $(0.005)$ \\
\hline 6 months ahead & $1.50^{* * *}$ & $(0.009)$ & $0.34^{* * *}$ & $(0.001)$ & $-1.92^{* * *}$ & $(0.016)$ & $0.97^{* * *}$ & $(0.004)$ \\
\hline 3 months ahead & $1.10^{* * *}$ & $(0.006)$ & $0.61^{* * *}$ & $(0.002)$ & $-1.51^{* * *}$ & $(0.008)$ & $0.98^{* * *}$ & $(0.003)$ \\
\hline
\end{tabular}

(Notes) (i) Estimation of the equation $\left.r_{t}=\rho r_{t-1}+(1-\rho) \alpha+(1-\rho) \beta\left[\pi_{t+n} \mid \Omega_{t}\right]+(1-\rho) \gamma\left[x_{t} \mid \Omega_{t}\right]\right]+\varepsilon_{t}$ using GMM.

(ii) Standard errors of coefficients are presented in parentheses. Estimated weighting matrix based on Newey and West (1987) for computing HAC standard errors in EViews. Significance at 10\%, 5\%, and 1\% are denoted by $*, * *$, and $* * *$, respectively.

(iii) The same instrument set is used for $12,9,6$, and 3month horizon. Instruments are as follows: 8 lags each of interest rate, (HICP), output gap, world oil prices, and world commodity prices and a constant.

Based on the ECB's inflation forecast horizon, we notice that changing the horizon has no significant changes, except for minor coefficient changes. Moreover, all estimates are statistically significant. Then, inflation estimates are all greater than 1 and satisfy the Taylor principle, which states that a $1 \%$ percent inflation increase should induce the nominal interest rate to increase by more than $1 \%$ to affect the real interest rate. Following this condition, a monetary policy is effective according to the Taylor principle. Thus, our baseline model for the ECB is robust to changes in inflation forecast horizons between 3- and 12-month periods based on our estimation results.

Table 3. Changing the Inflation Forecast Horizons for the Riksbank ( $\beta=$ Inflation Estimate; $\gamma=$ Output Gap Estimate; $\alpha=$ Constant; and $\rho=$ Estimate for Smoothing Parameter)

\begin{tabular}{llllll}
\hline & \multicolumn{1}{c}{$\gamma$} & $\gamma$ & \multicolumn{2}{c}{$a$} & $\rho$ \\
\hline 12 months ahead & $1.92^{* * *}(0.008)$ & $0.98^{* * *}(0.002)$ & $-2.28^{* * *}(0.016)$ & $0.98^{* * *}(0.006)$ \\
9 months ahead & $5.58^{* * *}(0.009)$ & $1.30^{* * *}(0.001)$ & $-7.39^{* * *}(0.018)$ & $0.99^{* * *}(0.006)$ \\
6 months ahead & $3.17^{* * *}(0.009)$ & $0.35^{* * *}(0.002)$ & $-3.60^{* * *}(0.015)$ & $0.98^{* * *}(0.005)$ \\
3 months ahead & $0.95^{* * *}(0.008)$ & $0.46^{* * *}(0.002)$ & $-0.86^{* * *}(0.011)$ & $0.97^{* * *}(0.006)$ \\
\hline
\end{tabular}

(Notes) (i) Estimation of the equation $\left.r_{t}=\rho r_{t-1}+(1-\rho) \alpha+(1-\rho) \beta\left[\pi_{t+n} \mid \Omega_{t}\right]+(1-\rho) \gamma\left[x_{t} \mid \Omega_{t}\right]\right]+\varepsilon_{t}$ using GMM. Standard errors of coefficients are presented in parentheses. Estimated weighting matrix based on Newey and West (1987) for computing HAC standard errors in EViews. Significance at 10\%, 5\%, and $1 \%$ are denoted by $* * *$, and $* * *$, respectively.

(ii) For 12, 9, 6, and 3-month horizon, we used the same instruments sets, namely, 8 lags of repo rate, 12 lags of inflation (HICP), 8 lags of output gap, 8 lags of world oil prices, and a constant.

In the case of the Riksbank, 9- and 6-month inflation horizons produce high inflation and constant term estimates, though all coefficients are statistically significant. Three-month inflation forecast horizon produces low inflation estimates, that is, below 1. All horizons result in positive inflation and output gap estimates. The 12-month inflation horizon produces realistic estimates for all variables. According to Berg et al. (2004), the Riksbank inflation forecast is between 
12 and 24 months, which is dependent on the unchanged repo rate. Hence, we stick to our baseline assumption of 12-month inflation forecast for the Riksbank as an appropriate Taylor inflation horizon. Table 3 shows estimation results for the Riksbank after changing the inflation forecast horizon.

\section{Augmenting the baseline model}

The previous section discusses that central banks are forward-looking when conducting monetary policy and will therefore react to anticipated inflation. We aim to explore how our baseline model appropriately describes the two banks' actual monetary policy. Thus, we augment the model with other variables that can explain the two central banks' nominal interest rate behavior. We individually incorporate these variables into the reaction function and analyze the effect.

Considering the empirical literature, authors such as Gerlach and Schnabel (2000) included an exchange rate in the Taylor rule model. Österholm (2005) augmented an open economy Taylor-type reaction function with foreign interest rates and exchange rates. Ball (1999) also found that including exchange rate in policy rules can improve the macroeconomic performance in open economies. Gerlach and Schnabel (2000) argued that the original Taylor rule does not have variables to account for during periods of strong exchange rate volatilities. Svensson (2002) also supported this finding by stating that the original Taylor rule may not capture the dynamics of such variables during external shocks in open economies, hence its inadequacy. Next, we augment the baseline model by adding certain potential variables to ascertain whether the baseline model estimates will change. In other words, we aim to examine coefficient behavior of the baseline model given additional specifications. Then, we make a comparison with the baseline model to determine coefficient changes. Potential variables that are incorporated into the reaction function includes real exchange rate, money growth rate (M3), Fed funds rate (in the ECB's case), the ECB's interest rate (in the Riksbank's case), and lagged inflation. These variables are selected due to two main reasons. First, we selected these variables from existing literature. Second, we find evidence of a positive correlation ${ }^{7)}$ between these variables and the actual monetary policy instrument (short-term interest rates). Table 4 below shows the estimation results after additional regressions have been incorporated into the baseline reaction functions for the ECB.

7) Table $10 \mathrm{~s}$ and 11 and the Appendix illustrates the correlation matrix for all the variables. 
Table 4. Augmenting the Baseline Model with Additional Variables for ECB

\begin{tabular}{|c|c|c|c|c|c|c|}
\hline & $\beta$ & $\gamma$ & $a$ & $\rho$ & $\varphi$ & J.Stats \\
\hline Baseline $^{a}$ & $\begin{array}{l}1.15^{* * *} \\
(0.008)\end{array}$ & $\begin{array}{l}0.57^{* * *} \\
(0.001)\end{array}$ & $\begin{array}{l}-1.37^{* * *} \\
(0.014)\end{array}$ & $\begin{array}{l}0.97^{* * *} \\
(0.004)\end{array}$ & & 21.50 \\
\hline \multicolumn{7}{|l|}{ Adding } \\
\hline Real Exch rate ${ }^{b}$ & $\begin{array}{l}0.51^{* * *} \\
(0.006)\end{array}$ & $\begin{array}{l}0.45^{* * *} \\
(0.002)\end{array}$ & $\begin{array}{c}-10.48^{* * *} \\
(0.13)\end{array}$ & $\begin{array}{l}0.95^{* * *} \\
(0.008)\end{array}$ & $\begin{array}{l}0.10^{* * *} \\
(0.001)\end{array}$ & 23.90 \\
\hline Money growth ${ }^{c}$ & $\begin{array}{l}1.04^{* * *} \\
(0.006)\end{array}$ & $\begin{array}{l}0.57^{* * *} \\
(0.001)\end{array}$ & $\begin{array}{l}-1.56^{* * *} \\
(0.018)\end{array}$ & $\begin{array}{l}0.97^{* * *} \\
(0.007)\end{array}$ & $\begin{array}{c}0.076 \\
(0.003)\end{array}$ & 23.50 \\
\hline Fed funds rate ${ }^{d}$ & $\begin{array}{l}0.26^{* *} \\
(0.007)\end{array}$ & $\begin{array}{l}0.27^{* * *} \\
(0.001)\end{array}$ & $\begin{array}{l}-0.55^{* * *} \\
(0.011)\end{array}$ & $\begin{array}{l}0.94^{* * *} \\
(0.007)\end{array}$ & $\begin{array}{l}0.76^{* *} \\
(0.004)\end{array}$ & 24.74 \\
\hline Lagged inflation $^{e}$ & $\begin{array}{l}1.89^{* * *} \\
(0.007)\end{array}$ & $\begin{array}{l}0.94^{* * *} \\
(0.001)\end{array}$ & $\begin{array}{l}-1.36^{* *} \\
(0.016)\end{array}$ & $\begin{array}{l}0.98^{* * *} \\
(0.006)\end{array}$ & $\begin{array}{c}1.0^{* *} \\
(0.008)\end{array}$ & 21.14 \\
\hline
\end{tabular}

(Notes) (i) Estimation of the equation $\left.r_{t}=\rho r_{t-1}+(1-\rho) \alpha+(1-\rho) \beta\left[\pi_{t+n} \mid \Omega_{t}\right]+(1-\rho) \gamma\left[x_{t} \mid \Omega_{t}\right]\right]+(1-$ $\left.\rho) \phi\left[h_{t} \mid \Omega_{t}\right]\right]+\varepsilon_{t}$ using GMM, where $h$ and $\phi$ represents the additional regressor and estimate, respectively.

(ii) Standard errors of coefficients are presented in parentheses. Estimated weighting matrix based on Newey and West (1987) for computing of HAC standard errors in EViews. Significance at $10 \%, 5 \%$, and $1 \%$ are denoted by $*, * *$, and ***, respectively.

(iii) ${ }^{a}$ Baseline model with 12-month inflation forecast horizon. Instruments are 8 lags each of the interest rates (EONIA), inflation (HICP), output gap, money growth rate for the euro area, world commodity prices, and world oil prices and a constant

${ }^{b}$ Instruments are 8 lags each of interest rates, inflation, output gap, world commodity prices, world oil prices, and real exchange rate and a constant

${ }^{c} 8$ lags each of interest rate, inflation, output gap, world commodity prices, world oil prices, and money growth rate in the euro area and a constant

${ }^{d} 8$ lags each of interest rate, inflation, output gap, world commodity prices, and Federal funds rate, and a constant

${ }^{e} 8$ lags each of interest rate, inflation, output gap, world commodity prices, and world oil prices, and a constant

We use the real exchange rate in the reaction function for the ECB. We observe a positive inflation estimate, which is lower than unity $(\beta=0.51)$, and a low estimate for output gap $(\gamma=0.45)$ is also recorded. All estimates are statistically significant, including the real exchange rate. The standard errors for all the coefficients are lower than unity, whereas a higher monetary policy inertia is evident $(\rho=0.95)$. Figure 3(a) shows comparison between the augmented baseline model and exchange rate passed through against the actual series. A significant deviation is noticed between the two rates, which does not significantly differ from our baseline ECB model. Hence, the real exchange rate does not significantly impact the ECB's monetary policy, though it is statistically significant.

Next, we include the euro area's money growth rate in the reaction function. According to Castro (2011), the ECB's monetary pillar suggests that it should target the euro area's money growth. Thus, augmenting the baseline model with money growth is important. Thus, coefficients of inflation, output gap, money growth, and the smoothing parameter are statistically significant at $1 \%$ level with low standard errors. The inflation estimate is also positive and greater than $1(\beta=1.04)$, whereas the output gap estimate $(\gamma=0.57)$ is positive. Hence, the regime is characterized by stabilization in the context of new Keynesian macroeconomics (see Clarida 
et al., 2000). Monetary policy inertia is still high $(\rho=0.97)$, whereas standard errors are all below 1 . It is noteworthy that money growth estimate $(\varphi=0.23)$ is not statistically significant for our augmented baseline model. This finding is consistent with Fourçans and Vranceanu (2002) and Castro (2011) who both found that the ECB does not react to the euro area's money growth. Figure 3(b) shows that augmenting the model with the euro area's money growth does impact the baseline model.

We augment the baseline model with the Federal funds rate and notice that all regressors are significant statistically at $1 \%$ level, except for inflation, which is significant at $5 \%$ level. In addition, inflation and output gap estimates are less than $1(\alpha=0.26$ and $\beta=0.27)$. The low parameter estimate indicates a Taylor principle violation and a destabilizing regime. We also noticed a slight drop in the smoothing parameter $(\rho=0.94)$, suggesting less inertia in monetary policy. Figure 3(c) shows that augmenting the baseline model with the Fed funds rate significantly explains the ECB's monetary policy compared with other variables. We observe that the two graphs move in the same direction with slight deviations and narrow confidence band.

Finally, we augment the baseline model with lagged inflation and observe that all other regressors are statistically significant, including lagged inflation. The policy regime is characterized

Figure 3. Augmented baseline taylor rule for the european central bank (ECB)
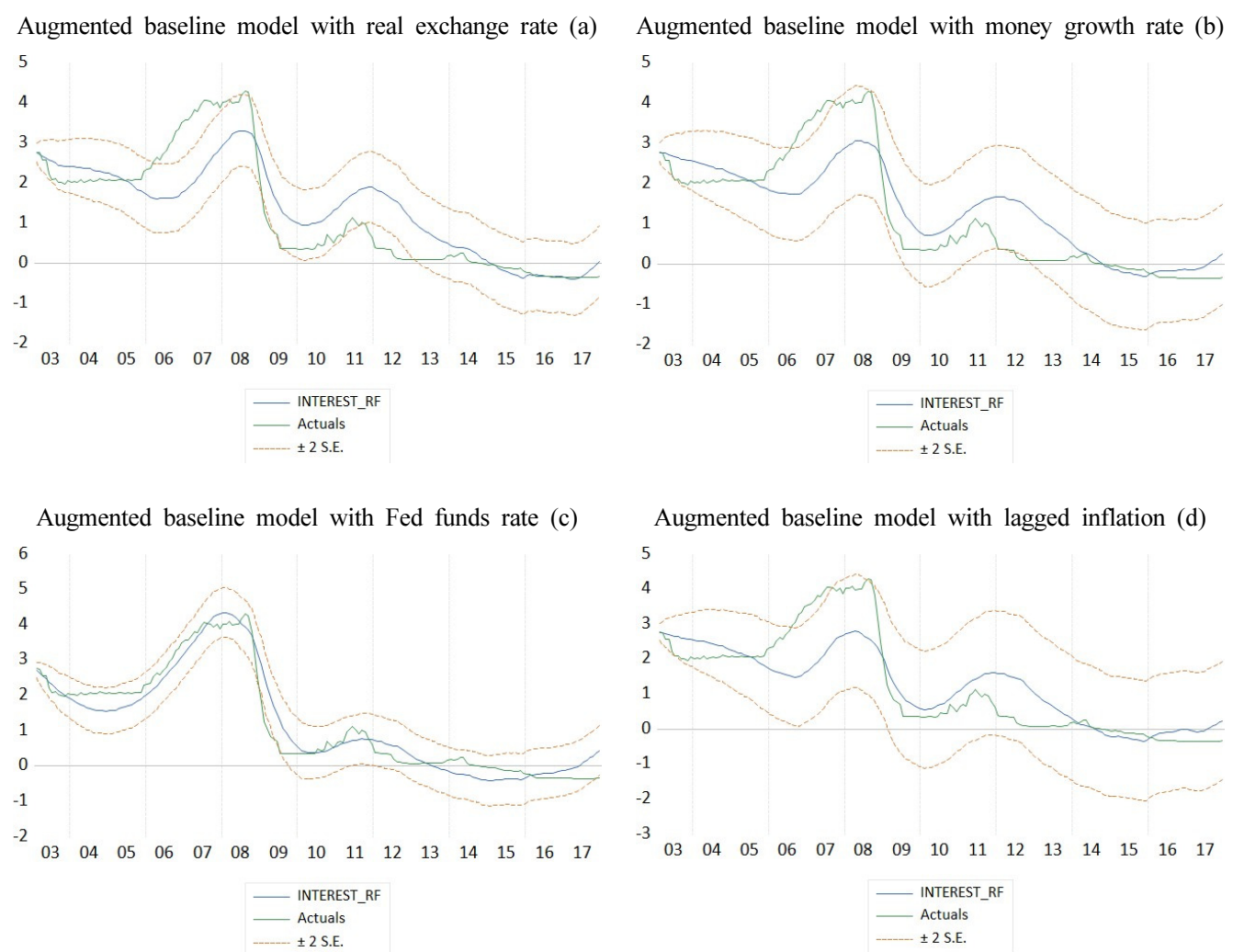
by a stabilizing regime, whereas monetary policy inertia is still high. Figure 3(d) shows how the augmented baseline model with lagged inflation tracks the actual interest rate. We observe that the augmented baseline model with lagged inflation does not significantly track the actual interest rate. Hence, we infer that lagged inflation does not impact the baseline Taylor model.

In the case of the Riksbank, we first incorporate real exchange rate into the reaction function. Altohugh all variables are statistically significant, the inflation estimate $(\beta=0.85)$ is positive but less than 1 , whereas the output gap estimate is also low $(\gamma=0.29)$. Moreover, a high monetary policy inertia is evident $(\rho=0.94)$, whereas a negative but higher intercept term $(\alpha=-20.98)$ is recorded with low standard errors. Table 5 depicts the augmented model's estimation results. Figure 4(a) shows that the augmented model significantly mimics the paths of the Riksbank's actual monetary policy. This finding suggests that the Riksbank considers the real exchange rate when conducting a monetary policy.

Table 5. Augmenting the Baseline Model with Additional Variables for the Riksbank

\begin{tabular}{|c|c|c|c|c|c|c|}
\hline & $\beta$ & $\gamma$ & $a$ & $\rho$ & $\varphi$ & J.Stats \\
\hline Baseline $^{a}$ & $\begin{array}{l}1.92^{* * *} \\
(0.008)\end{array}$ & $\begin{array}{l}0.98^{* * *} \\
(0.002)\end{array}$ & $\begin{array}{l}-2.28^{* * *} \\
(0.016)\end{array}$ & $\begin{array}{l}0.98^{* * *} \\
(0.006)\end{array}$ & & 26.27 \\
\hline \multicolumn{7}{|l|}{ Adding } \\
\hline Real Exch rate ${ }^{b}$ & $\begin{array}{l}0.85^{* * *} \\
(0.006)\end{array}$ & $\begin{array}{l}0.29^{* * *} \\
(0.001)\end{array}$ & $\begin{array}{c}-20.98^{* * *} \\
(0.13)\end{array}$ & $\begin{array}{l}0.94^{* * *} \\
(0.005)\end{array}$ & $\begin{array}{l}0.20^{* * *} \\
(0.001)\end{array}$ & 26.96 \\
\hline Money growth ${ }^{c}$ & $\begin{array}{l}2.40^{* * *} \\
(0.007)\end{array}$ & $\begin{array}{l}1.0^{* * *} \\
(0.001)\end{array}$ & $\begin{array}{l}-2.03^{* * *} \\
(0.0013)\end{array}$ & $\begin{array}{c}0.98^{*} \\
(0.005)\end{array}$ & $\begin{array}{l}-1.33^{* * *} \\
(0.011)\end{array}$ & 27.51 \\
\hline $\mathrm{ECB}$ interest $^{d}$ & $\begin{array}{c}0.011 \\
(0.007)\end{array}$ & $\begin{array}{c}0.187^{* * *} \\
(0.001)\end{array}$ & $\begin{array}{c}-0.191^{* *} \\
(0.016)\end{array}$ & $\begin{array}{l}0.88^{* * *} \\
(0.016)\end{array}$ & $\begin{array}{l}0.76^{* * *} \\
(0.014)\end{array}$ & 27.13 \\
\hline Lagged Inflat $^{e}$ & $\begin{array}{l}4.55^{* * *} \\
(0.009)\end{array}$ & $\begin{array}{l}2.52^{* * *} \\
(0.002)\end{array}$ & $\begin{array}{l}-2.91^{*} \\
(0.015)\end{array}$ & $\begin{array}{l}0.99^{* * *} \\
(0.006)\end{array}$ & $\begin{array}{l}-3.75^{* * *} \\
(0.010)\end{array}$ & 24.18 \\
\hline
\end{tabular}

(Notes) (i) Estimation of the equation $\left.r_{t}=\rho r_{t-1}+(1-\rho) \alpha+(1-\rho) \beta\left[\pi_{t+6} \mid \Omega_{t}\right]+(1-\rho) \gamma\left[x_{t} \mid \Omega_{t}\right]\right]+(1-$ o) $\left.\gamma\left[h_{t} \mid \Omega_{t}\right]\right]+\varepsilon_{t}$ using GMM, where $h$ and $\phi$ represents the additional regressor and the estimate, respectively.

(ii) Standard errors of coefficients are presented in parentheses. Estimated weighting matrix based on Newey and West (1987) for computing HAC standard errors. Significance at $10 \%, 5 \%$, and $1 \%$ are denoted by $*, * *$, and ***, respectively.

(iii) ${ }^{a}$ Baseline model with 12-month inflation forecast horizon

${ }^{b}$ Instruments are 8 lags of repo rate, 12 lags of inflation, 8 lags of output gap, 8 lags of world oil prices, 8 lags of real exchange rate, and a constant.

${ }^{c} 8$ lags of repo rate, 12 lags of inflation, 8 lags of output gap, 12 lags of world oil prices, 8 lags of money growth, and a constant

${ }^{d} 8$ lags of repo rate, 12 lags of inflation, 8 lags of output gap, 8 lags of world commodity prices, 8 lags of world oil prices, 8 lags of ECB interest rates, and a constant

${ }^{e} 8$ lags of repo rate, 12 lags of inflation, 8 lags of output gap, 8 lags of world commodity prices, 8 lags of world oil prices, and a constant

Second, we augment the reaction function with Sweden's money growth rate (M3). We notice that all regressors are significant at $1 \%$ level. Third, inflation and output gap estimates are all positive, implying a stabilizing monetary policy. The monetary policy inertia is significantly high 
$(\rho=0.98)$ at $1 \%$ significant level. Figure 4(b) shows the path of the augmented model compared with the actual rate. Significant deviations are noticed between the two interest rates as money growth does significantly not impact the baseline model to track the actual repo rate.

We augment the baseline reaction function with the ECB's interest rate. We notice that all variables are statistically significant, except for expected inflation. Inflation estimate $(\beta=0.011)$ is low compared with output gap estimate $(\gamma=0.0045)$. We also observe reduced monetary policy inertia $(\rho=0.88)$, which is still significantly high. Figure 4(c) shows that the augmented model with the ECB interest rate significantly tracks the actual rate with lower confidence bands, though not perfectly. This finding implies that the ECB interest rate explains the Riksbank's monetary policy to some extent. However, issues of low and statistically insignificant inflation estimates raise concerns regarding violation to the Taylor principle.

Lastly, after including lagged inflation rate in the reaction function, we observe high inflation estimate $(\beta=4.55)$, whereas the output gap estimate $(\gamma=2.52)$ is also high and greater than 1. All estimates are statistically significant. Figure 4(d) shows that augmenting the baseline model with lagged inflation tracks the actual interest rate but with wider confidence bands.

Figure 4. Augmented baseline taylor rule for the riksbank

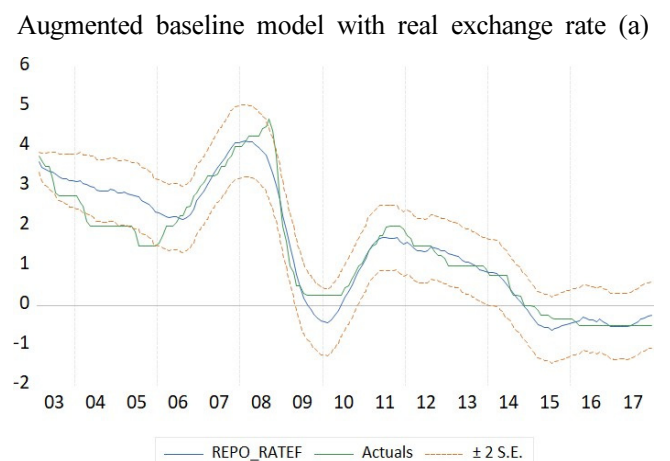

Augmented baseline model with money growth rate (b)

5

3

2

1

$-1$

$-3$

$\begin{array}{lllllllllllllll}03 & 04 & 05 & 06 & 07 & 08 & 09 & 10 & 11 & 12 & 13 & 14 & 15 & 16 & 17\end{array}$

— REPO_RATEF — Actuals - \pm 2 S.E.
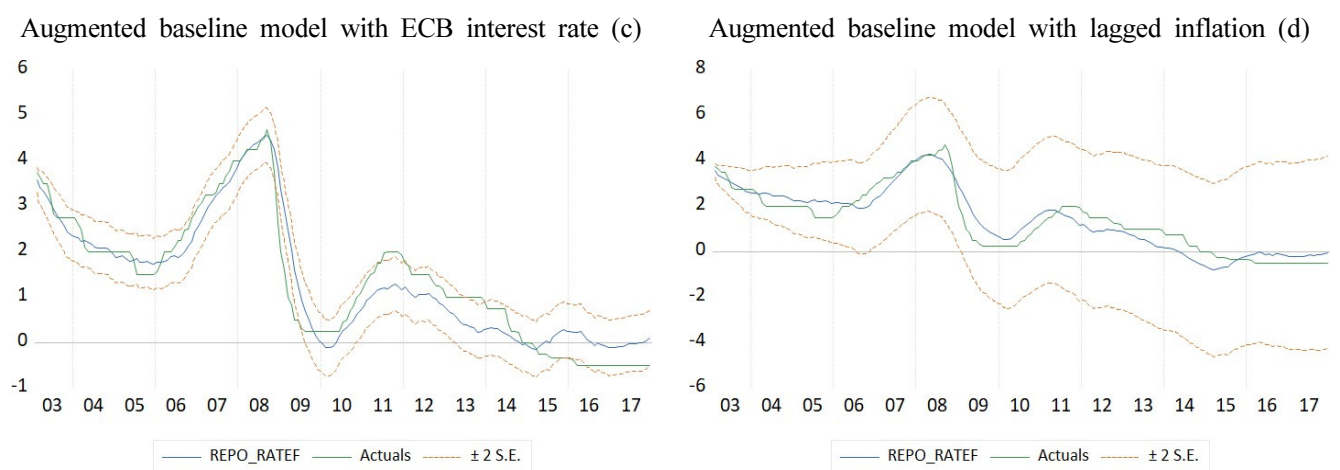


\section{Summary and Conclusion}

This study aims to compare the monetary policy of a currency union with a non-currency union central bank. The EMU is selected being the world's largest currency union. Sweden is a member of the EU and has an independent monetary policy. Ter Ellen et al. (2018) found that the ECB monetary policy's spillover affects the Swedish monetary policy, being a neighbor of the euro area with significant trading relations. Other authors, such as Goczek and Partyka (2019), have suggested that the euro area explains the domestic monetary policy of smaller open economies in the EEA area, such as Sweden. Moreover, the Swedish and euro area's business cycles significantly correlate, implying that both economies are driven by common shocks (Söderström, 2008). Given this situation, comparing the Swedish monetary policy and that of the euro area becomes interesting. This study has estimated and compared the Taylor rule type monetary policy reaction function between the ECB and Riksbank during 2003:1-2018:12. The paper derived a forward-looking Taylor rule specification with interest rate smoothing as motivated by Clarida et al. (1998). First, we estimated a baseline model for the ECB and Riksbank. The study found that both banks' regime can be described as stabilizing due to inflation estimates greater than 1 and are characterized by positive output gap weights. The baseline model's empirical results showed that the Riksbank is the aggressor between the two banks with regard to responding to anticipated inflation deviations from actual inflation. Second, the Riksbank shows much stronger response to output deviations compared with the ECB. The results also show monetary policy inertia by the two central banks, implying a high degree of interest rate smoothing by the two banks. After plotting and comparing the baseline Taylor model with the actual interest rates, we observed that the Riksbank's baseline model significantly mimics the actual interest rate compared with the ECB, though certain deviations exist. The Riksbank conceded in its September 2017 economic commentary that its monetary policy is in line with the so Taylor rule, though it stresses in the letter that it does not follow the rule. Researchers such as Svensson (2003), Rudebusch and Svensson (1998), and Taylor (2000) have stressed that such instrument rules may only for monetary policies and may not be followed mechanically. We observed that the baseline model does not perfectly fit the actual interest rate for both regimes. The ECB does not commit to follow a Taylor-type rule in practice.

Our first robustness test shows that this study used baseline model results to compute the two central banks' inflation targets because price stability has been defined as the primary objective of their respective monetary policies. Our baseline model predicted an inflation target of $2.18 \%$ and $1.86 \%$ for the ECB (approximately equals the $2 \%$ official target) and Sweden (equals the $2 \%$ official target), respectively. Therefore, the baseline model provided a reasonable approximation of inflation target for both regimes, showing certain robustness. 
With the two central banks' forward-looking behavioral assumption, this study assumed a 12-month inflation forecast horizon for the ECB and Riksbank. We explored different inflation forecast horizons as another robustness test and found out that the ECB reaction function is more robust to inflation forecast changes, whereas the Riksbank reaction function is less robust to such changes. Finally, although the baseline model for the ECB and Riksbank significantly tracks their respective actual interest, significant deviations exist. We augmented our baseline model by considering variables that have been used by other researchers in previous studies. By doing this, we arrive at a monetary policy reaction function that describes the two central banks' monetary policy. These variables relate with the central banks' actual monetary policies. Real exchange rate, money growth rate, foreign interest rate, and lagged inflation were considered as variables that likely impact the central banks' monetary policy decisions.

We analyze the above results for the two central banks and observe that the Fed funds rate impacts the ECB's monetary policy more than the other regressors. In the case of the Riksbank, we found two additional regressors that help describe its monetary policy, namely, real exchange rate and the ECB's interest rate (foreign interest rate). On the contrary, the results show that the real exchange rate does not significantly impact the ECB's monetary policy. This finding suggests that small open economies are more concerned about exchange rate volatilities in their major trading partners compared with bigger economies. Our results are consistent with Svensson (2000), who held that exchange rates in a small open economy play a key role in the monetary policy transmission mechanism. Possible reasons could be that exchange rate variations affect international trade with implications on the quantity of imports, exports, and prices at which goods and services are evaluated (Harms, 2016). Lastly, the studies found that foreign interest rates, particularly from other bigger economies, influence both regimes. We have observed that although the Riksbank considers the ECB's the monetary policy in its decision-making, the ECB also reacts significantly to the Fed funds rate (US monetary policy).

\section{References}

Aoki, K. (2001). Optimal monetary policy responses to relative-price changes. Journal of Monetary Economics, 48(1), 55-80.

Ball, L. (1999). Efficient rules for monetary policy. International Finance, 2(1), 63-83.

Beck, G. W., \& Wieland, V. (2008). Central bank misperceptions and the role of money in interest rate rules. Journal of Monetary Economics, 55(1), 1-17.

Belke, A., \& Klose, J. (2010). (How) Do the ECB and the fed react to financial market uncertainty? The Taylor Rule in Times of Crisis. Discussion Papers of DIW Berlin, 972.

Berge, C., \& Gröttheim, M. (1997). Monetary policy in Sweden since 1992. BIS Policy Papers, 2, 140-182. 
Berg, C., Jansson, P., \& Vredin, A. (2004). How useful are simple rules for monetary policy? (Sveriges Riksbank Working Paper Series, No. 169). The Swedish experience, Stockholm.

Castro, V. (2011). Can central banks' monetary policy be described by a linear (augmented) Taylor rule or by a nonlinear rule? Journal of Financial Stability, 7(4), 228-246.

Clarida, R., Galì, J., \& Gertler, M. (1998). Monetary policy rules in practice. European Economic Review, 42(6), 1033-1067.

Clarida, R., Galí, J., \& Gertler, M. (2000). Monetary policy rules and macroeconomic stability: Evidence and some theory. Quarterly Journal of Economics, 115(1), 147-180.

Drakos, A. A., \& Kouretas, G. P. (2015). The conduct of monetary policy in the Eurozone before and after the financial crisis. Economic Modelling, 48, 83-92.

Faust, J., \& Henderson, D. W. (2004). Is inflation targeting best-practice monetary policy? (FRB International Finance Discussion Paper No. 807).

Fourçans, A., \& Vranceanu R. (2002). ECB monetary policy rule: Some theory and empirical evidence (ESSEC Working Paper No.02008).

Friedman, B. M. (2004). Why the Federal Reserve Should Not Adopt Inflation Targeting. International Finance, 7(1), 129-136.

Fuhrer, J. C. (1997). Inflation/output variance trade-offs and optimal monetary policy. Journal of Money, Credit and Banking, Blackwell Publishing, 29(2), 214-234.

Galí, J., \& Monacelli, T. (2005). Monetary policy and exchange rate volatility in a small open economy. The Review of Economic Studies, Oxford University Press, 72(3), 707-734.

Galimberti, J. K., \& Moura, M. L. (2013). Taylor rules and exchange rate predictability in emerging economies. Journal of International Money and Finance, 32(1), 1008-1031.

Gerdesmeier, D., \& Roffia, B. (2003). Empirical estimates of reaction functions for the euro area (ECB Working Paper Series No. 206).

Gerlach, S., \& Schnabel, G. (2000). The Taylor rule and interest rates in the EMU Area: A Note. SSRN Electronic Journal, 67, 165-171.

Giovazzi, F., \& Mishkin, F. S. (2006). An Evaluation of Swedish Monetary Policy 1995-2005, In Reports from the Riksdag 2006/07:RFR 1, Committee on Finance, Stockholm.

Goczek, Ł., \& Partyka, K. J. (2019). Too small to be independent? On the influence of ECB monetary policy on interest rates of the EEA countries. Economic Modelling, 78(C), 180-191.

Goodfriend, M. (1991). Interest rates and the conduct of monetary policy. Carnegie- Rochester Conference Series on Public Policy, 34, 7-30.

Hartmann, P., \& Smets, F. (2018). The first twenty years of the European Central Bank: monetary policy (ECB Working Paper Series, No. 2219).

Harms, P. (2016). International macroeconomics (2nd ed.). Tübingen: Mohr Siebeck.

Hayo, B., \& Hofmann, B. (2006). Comparing monetary policy reaction functions: ECB versus Bundesbank. Empirical Economics, 31(3), 645-662.

Ilbas, P., Røisland, Ø., \& Sveen, T. (2012). Robustifying optimal monetary policy using simple rules as cross-checks (Norges Bank Working Paper, No 22).

Levin, A., \& Williams, J. C. (2003). Robust Monetary policy with competing reference models (FRB 
of San Francisco Working Paper No. 2003-10).

Lubik, T., \& Schorfheide, F. (2007). Do central banks respond to exchange rate movements? A structural investigation. Journal of Monetary Economics, 54(4), 1069-1087.

McCallum, B. T. (1996). Inflation targeting in Canada (NBER Working Paper No. 5529). New Zealand, Sweden, the UK and in general.

McCallum, B. T., \& Nelson, E. (1999). An Optimizing IS-LM Specification for monetary policy and business cycle analysis. Journal of Money, Credit, and Banking, 31, 296-316.

Newey, W. K., \& West, K. D. (1987). A simple, positive semi-definite, heteroskedasticity and autocorrelation consistent covariance matrix. Econometrica, 55, 703-708.

Orphanides, A. (2001). Monetary policy rules based on real-time data. The American Economic Review, 91(4), 964-985.

Österholm, P. (2005). The Taylor rule: A spurious regression? Bulletin of Economic Research, 57(3), 217-247.

Peersman, G., \& Smets, F. (1999). The Taylor rule: A useful monetary policy benchmark for the Euro area? International Finance, 2(1), 85-116.

Rotemberg, J. J., \& Woodford, M. (1997). An optimization-based econometric framework for the evaluation of monetary policy. NBER Macroeconomics Annual, 12, 297-346.

Rudebusch, G. D. (2002). Assessing Nominal Income Rules for Monetary Policy with Model and Data Uncertainty. Economic Journal, 112(479), 402-432.

Rudebusch, G. D., \& Svensson, L. E. O. (1998). Policy rules for inflation target (Sveriges Riksbank Working Paper Series No. 49).

Sauer, S., \& Sturm, J. E. (2003). Using Taylor Rules to understand ECB Monetary Policy, CESIFO Working Paper No. 1110.

Söderström, U. (2008). Re-evaluating Swedish membership in EMU: Evidence from an Estimated Model (Working Paper Series 227). Sveriges Riksbank.

Svensson, L. E. O. (2003). What is wrong with Taylor rules? Using judgment in monetary policy through targeting rules. Journal of Economic Literature, 41(2), 426-477.

Svensson, L. E. O. (2001). The zero bound in an open economy: A foolproof way of escaping from a liquidity trap. Monetary and Economic Studies, 19(1), 277-312.

Svensson, L. E. O. (2000). Open-economy inflation targeting. Journal of International Economics, 50(1), 155-183.

Svensson, L. E. O. (1997). Inflation forecast targeting: Implementing and monitoring inflation targets. European Economic Review, 41(6), 1111-1146.

Svensson, L. E. O., \& Woodford, M. (2003). Indicator variables for optimal policy. Journal of Monetary Economics, Elsevier, 50(3), 691-720.

Taylor, J. B. (1993). Discretion versus policy rules in practice. Carnegie Rochester Conference Series on Public Policy, 39(1), 195-214.

Taylor, J. B. (1999). The robustness and efficiency of monetary policy rules as guidelines for interest rate setting by the European central bank. Journal of Monetary Economics, 43(3), 655-679.

Ter Ellen, S., Jansen, E., \& Midthjell, N. L. (2018). ECB Spillovers and Domestic Monetary Policy Effectiveness in Small Open Economies (Norges Bank Working Paper 9/2018). 
Ullrich, K. (2003). A Comparison Between the Fed and the ECB: Taylor Rules (ZEW Discussion Paper No. 03-19).

Walsh, C. E. (2015). Goals and rules in central bank design. International Journal of Central Banking, $11(\mathrm{~S} 1), 295-352$.

Walsh, C. E. (2017). Monetary Theory and Policy (4th ed.). Cambridge, MA: The MIT Press.

Woodford, M. (2003). Interest and prices: Foundations of a theory of monetary policy. Princeton, NJ: Princeton University Press.

Wooldridge, J. M. (2001). Applications of generalized method of moments estimation. Journal of Economic Perspectives, 15(4), 87-100. 


\section{Appendix}

\section{Testing for stationarity}

The main variables from our study are the interest rates, inflation, and output gap for Sweden and the Euro area. The stationarity test was carried out in EViews and results are displayed in the appendix. The ADF test experimented different lag choices with an intercept term included in the test equation. For the Euro area, output gap is stationary at all the explored lag levels and inflation is stationary from 2 lags and above. In other words, the ADF rejected the null hypothesis of a unit root in the series in favour of stationarity. In the case of interest rate, real exchange rate, federal funds rate and money growth rate the ADF results implies that there is less evidence against the null hypothesis hence non-stationarity at level. Stationarity is tested again at the first difference at different lag levels and we observe that interest rate, real exchange rate, federal funds rate, and money growth rate are all $I(1)$.

For Swedish data, the output gap and money growth rate are stationary at all tested lag levels. Inflation, repo rate and real exchange rates are stationary at first difference $(I(1))$. It has been proven that the Dickey-Fuller test has low power against the alternative hypothesis in the case of small samples (Clarida et al., 1998). Banerjee et al. (1993) also argued that the ADF test fails to distinguish a near-integrated process from a non stationary process. The $\mathrm{ADF}$ can have lower power problems against relative trend stationarity alternatives in instances of conventional sample sizes (DeJong et al., 1992). Hence we rely on the assumption that the variables which are $I(1)$ for both the Euro area and Sweden are stationary for our sample. Details of stationarity test is displayed in below.

Table A1. ADF (Test at Level) - Euro Area Variables

\begin{tabular}{|c|c|c|c|c|c|c|c|}
\hline Variable $\quad$ Lags & 0 & 1 & 2 & 3 & 4 & 5 & 6 \\
\hline Inflation & -1.89 & -1.89 & $-2.76^{* * *}$ & $-2.76^{* * *}$ & $-2.76^{* * *}$ & $-2.76^{* * *}$ & $-2.76^{* * *}$ \\
\hline Output gap & $-2.60^{*}$ & $-2.60^{*}$ & $-2.60^{*}$ & $-3.90^{* * *}$ & $-3.90^{* * *}$ & $-3.90^{* * *}$ & $-3.90^{* * *}$ \\
\hline Interest rates & -0.69 & -1.3 & -1.59 & -1.59 & -1.59 & -1.59 & -1.3 \\
\hline Money growth & -1.09 & -1.09 & -1.09 & -2.0 & -2.27 & -2.27 & -2.27 \\
\hline Fed. funds rate & -0.46 & -1.28 & -1.28 & -1.28 & -1.28 & -1.28 & -1.44 \\
\hline Real Exch rate & -1.44 & -1.74 & -1.44 & -1.44 & -1.71 & -1.44 & -1.44 \\
\hline
\end{tabular}

(Note) Table presents reports on the value of t-statistics. Significance at $10 \%, 5 \%$ and $1 \%$ are denoted by $*$, ** and $* * *$ respectively 
Table A2. ADF (First Difference) - Euro Area Variables

\begin{tabular}{|c|c|c|c|c|c|c|c|}
\hline Variable $\quad$ Lags & 0 & 1 & 2 & 3 & 4 & 5 & 6 \\
\hline Interest rate & $-6.62^{* * *}$ & $-4.48^{* * *}$ & $-4.48^{* * *}$ & $-4.48^{* * *}$ & $-6.62^{* * *}$ & $-6.62^{* * *}$ & $-4.48^{* * *}$ \\
\hline Money growth & $-12.76^{* * *}$ & $-12.76^{* * *}$ & $-5.24^{* * *}$ & $-5.24^{* * *}$ & $-5.24^{* * *}$ & $-5.24^{* * *}$ & $-4.14^{* * *}$ \\
\hline Fed Funds rate & $-5.94^{* * *}$ & $-5.94^{* * *}$ & $-5.94^{* * *}$ & $-5.94^{* * *}$ & $-5.94^{* * *}$ & $-5.94^{* * *}$ & $-5.94^{* * *}$ \\
\hline Real Exch rate & $-11.77^{* * *}$ & $-11.77^{* * *}$ & $-11.77^{* * *}$ & $-11.77^{* * *}$ & $-11.77^{* * *}$ & $-11.77^{* * *}$ & $-11.77^{* * *}$ \\
\hline
\end{tabular}

(Note) Table presents reports on the value of t-statistics. Significance at $10 \%, 5 \%$ and $1 \%$ are denoted by $*$, ** and *** respectively

Table A3. ADF (Test at Level) - Swedish Variables

\begin{tabular}{|c|c|c|c|c|c|c|c|}
\hline Variable $\quad$ Lags & 0 & 1 & 2 & 3 & 4 & 5 & 6 \\
\hline Inflation & -2.24 & -2.24 & -2.24 & -2.24 & -2.24 & -2.24 & -2.24 \\
\hline Output gap & $-4.25^{* * *}$ & $-3.15^{* *}$ & $-3.15^{* *}$ & $-3.15^{* *}$ & $-3.15^{* *}$ & $-3.15^{* *}$ & $-3.15^{* *}$ \\
\hline Repo rate & -1.84 & -1.84 & -2.04 & -2.04 & -2.04 & -2.04 & -2.04 \\
\hline Money growth & $-7.44^{* * *}$ & $-8.27^{* * *}$ & $-5.50^{* * *}$ & $-5.50^{* * *}$ & $-3.85^{* * *}$ & $-3.85^{* * *}$ & $-3.08^{* * *}$ \\
\hline $\mathrm{ECB}$ interest rate & -0.69 & -1.3 & -1.59 & -1.59 & -1.59 & -1.59 & -1.3 \\
\hline
\end{tabular}

(Note) Table presents reports on the value of t-statistics. Significance at $10 \%, 5 \%$ and $1 \%$ are denoted by $*, * *$ and *** respectively

Table A4. $A D F$ (Test at First Difference) - Swedish Variables

\begin{tabular}{|c|c|c|c|c|c|c|c|}
\hline Variable ${ }^{\text {Lags }}$ & 0 & 1 & 2 & 3 & 4 & 5 & 6 \\
\hline Inflation & $-12.87^{* * *}$ & $-12.87^{* * *}$ & $-8.00^{* * *}$ & $-12.87^{* * *}$ & $-12.87^{* * *}$ & $-12.87^{* * *}$ & $-12.87^{* * *}$ \\
\hline Repo rate & $-6.41^{* * *}$ & $-4.86^{* * *}$ & $-4.86^{* * *}$ & $-4.86^{* * *}$ & $-6.41^{* * *}$ & $-4.86^{* * *}$ & $-4.86^{* * *}$ \\
\hline
\end{tabular}

(Note) Table presents reports on the value of t-statistics. Significance at $10 \%, 5 \%$ and $1 \%$ are denoted by $* * *$ and *** respectively

Table A5. Correlation Matrix - Euro Area Variables

\begin{tabular}{|c|c|c|c|c|c|c|c|c|}
\hline & $\begin{array}{l}\text { Int. } \\
\text { rate }\end{array}$ & Infla & $\begin{array}{l}\text { Out. } \\
\text { gap }\end{array}$ & $\begin{array}{l}\text { Money } \\
\text { growth }\end{array}$ & $\begin{array}{l}\text { Real } \\
\text { Exch. }\end{array}$ & $\begin{array}{l}\text { World } \\
\text { comm }\end{array}$ & $\begin{array}{l}\text { Fed } \\
\text { funds }\end{array}$ & $\begin{array}{c}\text { World } \\
\text { oil }\end{array}$ \\
\hline Interest rate & 1.0 & & & & & & & \\
\hline Inflation & 0.59 & 1.0 & & & & & & \\
\hline Output gap & 0.34 & 0.53 & 1.0 & & & & & \\
\hline Money growth & 0.80 & 0.38 & -0.31 & 1.0 & & & & \\
\hline Real Exch. & 0.75 & 0.39 & -0.09 & 0.41 & 1.0 & & & \\
\hline World comm & -0.14 & 0.27 & 0.32 & -0.41 & -0.10 & 1.0 & & \\
\hline Fed funds & 0.72 & 0.40 & 0.26 & 0.78 & 0.44 & -0.23 & 1.0 & \\
\hline World oil price & -0.08 & 0.32 & 0.31 & -0.37 & -0.03 & 0.98 & -10.18 & 1.0 \\
\hline
\end{tabular}


Table A6. Correlation Matrix - Swedish Variables

\begin{tabular}{lcccccccc}
\hline \multicolumn{1}{c}{ Repo rate } & $\begin{array}{c}\text { Repo } \\
\text { rate 1.0 }\end{array}$ & Infla & $\begin{array}{c}\text { Out. } \\
\text { gap }\end{array}$ & $\begin{array}{c}\text { Money } \\
\text { growth }\end{array}$ & $\begin{array}{c}\text { Real } \\
\text { Exch. }\end{array}$ & $\begin{array}{c}\text { World } \\
\text { comm }\end{array}$ & $\begin{array}{c}\text { Fed } \\
\text { funds }\end{array}$ & $\begin{array}{c}\text { World } \\
\text { oil }\end{array}$ \\
\hline Inflation & 0.49 & 1.0 & & & & & & \\
Output gap & 0.36 & 0.59 & 1.0 & & & & & \\
Money growth & 0.09 & 0.13 & 0.08 & 1.0 & & & & \\
Real Exch. & 0.77 & 0.14 & 0.32 & 0.03 & 1.0 & & & \\
World comm & 0.03 & 0.22 & 0.29 & -0.11 & 0.01 & 1.0 & & \\
Fed funds & 0.50 & 0.31 & 0.24 & 0.78 & 0.43 & 0.30 & 1.0 & \\
World oil price & 0.10 & 0.19 & 0.28 & -0.09 & 0.12 & 0.98 & -0.18 & 1.0 \\
\hline
\end{tabular}

Table A7. Varying the Measurement of Inflation for the ECB

\begin{tabular}{|c|c|c|c|c|c|c|c|c|}
\hline & \multicolumn{2}{|c|}{$\beta$} & \multicolumn{2}{|c|}{$\gamma$} & \multicolumn{2}{|c|}{$a$} & \multicolumn{2}{|c|}{$\rho$} \\
\hline Baseline(HICP) & $1.15^{* * *}$ & $(0.008)$ & $0.57^{* * *}$ & $(0.001)$ & $-1.37^{* * *}$ & $(0.014)$ & $0.97^{* * *}$ & $(0.004)$ \\
\hline Using CPI & $-0.17^{* * *}$ & $(0.002)$ & $0.39^{* * *}$ & $(0.003)$ & $17.58^{* * *}$ & $(0.23)$ & $0.94^{* * *}$ & $(0.002)$ \\
\hline Using GDP deflator & $-0.2^{* * *}$ & $(0.001)$ & $0.40^{* * *}$ & $(0.002)$ & $20.15^{* * *}$ & $(0.18)$ & $0.94^{* * *}$ & $(0.006)$ \\
\hline
\end{tabular}

(Notes) (i) Estimation of the equation $\left.r_{t}=(1-\rho) \alpha+\rho r_{t-1}+(1-\rho) \beta\left[\pi_{t+n} \mid \Omega_{t}\right]+(1-\rho) \gamma\left[x_{t} \mid \Omega_{t}\right]\right]+{ }_{t}$ using GMM. Where $n=12$ for the ECB. Standard errors of coefficients are depicted in parenthesis. Estimated weight-ing matrix based on Newey and West (1987) for computation of Heteroscedasticity and Autocorrelation corrected (HAC) standard errors in EViews.

(ii) Significance at $10 \%, 5 \%$ and $1 \%$ are denoted by $*, * *$ and $* * *$ respectively

(iii) Instruments consists of 8 lags of repo rates, 8 lags of output gap, 8 lags of inflation, 8 lags of the world oil prices prices, 8 lags of world commodity prices and a constant

Table A8. Varying the Measurement of Inflation for the Riksbank

\begin{tabular}{llllllll}
\hline & \multicolumn{2}{c}{$\beta$} & \multicolumn{2}{c}{$\gamma$} & \multicolumn{2}{c}{$a$} & $\rho$ \\
\hline Baseline(CPI) & $1.92^{* * * *}(0.008)$ & $0.98^{* * *}(0.002)$ & $-2.28^{* * *}(0.016)$ & $0.98^{* * *}(0.006)$ \\
Using HICP & -0.41 & $(0.012)$ & $0.69^{* * *}(0.002)$ & 0.70 & $(0.016)$ & $0.97^{* * *}(0.006)$ \\
Using GDP deflator & $-15.0^{* * *}(0.20)$ & $0.36^{* * *}(0.002)$ & $14.7^{* * *}(0.2)$ & $0.92^{* * *}(0.009)$ \\
Using CPIF & -0.65 & $(0.017)$ & $0.70^{* * *}(0.002)$ & 1.13 & $(0.025)$ & $0.97^{* * *}(0.006)$ \\
\hline
\end{tabular}

(Notes) (i) Estimation of the equation $\left.r_{t}=(1-\rho) \alpha+\rho r_{t-1}+(1-\rho) \beta\left[\pi_{t+n} \mid \Omega_{t}\right]+(1-\rho) \gamma\left[x_{t} \mid \Omega_{t}\right]\right]+{ }_{t}$ using GMM. Where $\mathrm{n}=12$ for the Riksbank. Standard errors of coefficients are depicted in parenthesis. Estimated weighting matrix based on Newey and West (1987) for computation of Heteroscedasticity and Auto correlation corrected (HAC) standard errors in EViews.

(ii) Significance at $10 \%, 5 \%$ and $1 \%$ are denoted by $* * *$ and $* * *$ respectively

(iii) Instruments consists of 8 lags of repo rates, 8 lags of output gap, 12 lags of inflation, 8 lags of the world oil prices prices and a constant 
Table A9. Summary Statistics - Euro Area

\begin{tabular}{lccccccc}
\hline & $\begin{array}{l}\text { Int. } \\
\text { rate }\end{array}$ & Infla & Out. gap & $\begin{array}{c}\text { Money } \\
\text { growth }\end{array}$ & $\begin{array}{c}\text { Real } \\
\text { Exch. }\end{array}$ & $\begin{array}{c}\text { World } \\
\text { comm }\end{array}$ & $\begin{array}{c}\text { Fed } \\
\text { funds }\end{array}$ \\
\hline Mean & 1.15 & 1.66 & $-7.59 \mathrm{E}-12$ & 5.06 & 100.15 & 128.13 & 1.36 \\
Median & 0.41 & 1.9 & 0.0009 & 4.85 & 99.88 & 122.01 & 0.41 \\
Maximum & 4.3 & 4.1 & 7.93 & 12.40 & 111.58 & 202.96 & 5.26 \\
Minimum & -0.37 & -0.6 & -11.09 & -0.4 & 86.95 & 62.2 & 0.07 \\
Std. Dev. & 1.45 & 0.99 & 2.77 & 3.16 & 6.25 & 35.48 & 1.66 \\
Skewness & 0.73 & -0.25 & -0.92 & 0.36 & -0.09 & 0.12 & 1.30 \\
Kurtosis & 2.21 & 2.58 & 6.36 & 2.33 & 1.93 & 2.06 & 3.36 \\
Observations & 192 & 192 & 192 & 192 & 192 & 192 & 192 \\
\hline
\end{tabular}

Table A10. Summary Statistics - Sweden

\begin{tabular}{lccccccc}
\hline & $\begin{array}{l}\text { Int. } \\
\text { rate }\end{array}$ & Infla & Out. gap & $\begin{array}{c}\text { Money } \\
\text { growth }\end{array}$ & $\begin{array}{c}\text { Real } \\
\text { Exch. }\end{array}$ & $\begin{array}{c}\text { ECB } \\
\text { Int. }\end{array}$ & $\begin{array}{c}\text { World } \\
\text { oil }\end{array}$ \\
\hline Mean & 1.31 & 1.17 & $-5.22 \mathrm{E}-12$ & 0.54 & 101.99 & 1.15 & 71.80 \\
Median & 1.25 & 1.10 & 0.47 & 0.53 & 104.28 & 0.41 & 67.35 \\
Maximum & 4.67 & 4.40 & 8.14 & 2.90 & 114.65 & 4.3 & 132.72 \\
Minimum & -0.50 & -1.9 & -13.39 & -1.33 & 87.96 & -0.37 & 25 \\
Std. Dev. & 1.44 & 1.23 & 3.79 & 0.69 & 7.08 & 1.45 & 28.07 \\
Skewness & 0.43 & 0.37 & -0.71 & 0.41 & -0.29 & 0.73 & 0.30 \\
Kurtosis & 2.23 & 2.88 & 4.54 & 3.87 & 1.90 & 2.21 & 1.95 \\
Observations & 192 & 192 & 192 & 192 & 192 & 192 & 192 \\
\hline
\end{tabular}

